\title{
Cultural heritage and memory: untangling the ties that bind
}

\author{
Dacia Viejo-Rose \\ Department of Archaeology and Anthropology \& McDonald Institute for Archaeological Research, University of Cambridge, \\ Downing Street, Cambridge CB2 3ER, UK \\ e-mail:dv230@cam.ac.uk
}

Submitted: 19 January 2015. Accepted: 29 May 2015

\begin{abstract}
Today in heritage studies memory looms larger than ever, there are memory parks, memory politics, and memory wars, there is discussion of 'dissonant', 'dark', and 'difficult' heritage linked to memories of traumatic past events. But what to we mean when we use the word 'memory' in the field of heritage? How is the divide between its social and individual realms bridged? This article theorizes the intimate relationship between heritage and memory by focusing on three areas. First, it maps out the vocabulary that has emerged from the heritage-memory dyad including how notions of collective memory and lieux de mémoire have been used, and occasionally misused, as well as the metaphors employed in the process. Second, the emergence of memory studies is considered, providing a brief overview of its foundations as well as assessing how it differs from, overlaps with, and contributes to heritage research. A third section offers a brief review of recent developments in cognitive psychology, neuroscience, and evolutionary biology relating to memory and how this might inform heritage studies. The concluding discussion provides a synthesis of the theoretical and empirical contribution of memory research to furthering out understanding of cultural heritage and proposes directions for future work on the area of confluence between the two.
\end{abstract}

KEYWORDS: Cultural heritage; memory; cultural memory; neuroscience; memes; lieux de mémoire; cognitive psychology.

Citation / Cómo citar este artículo: Viejo-Rose, Dacia (2015) "Cultural heritage and memory: untangling the ties that bind.” Culture \& History Digital Journal, 4(2): e018. doi: http://dx.doi.org/10.3989/chdj.2015.018.

RESUMEN: Patrimonio cultural y memoria: desenredar conceptos.- La memoria impregna hoy como nunca antes los estudios del patrimonio. Hay parques, políticas y guerras de la memoria. Se habla de un patrimonio "disonante", "oscuro" o "difícil" vinculado al recuerdo de pasados sucesos traumáticos. Pero, ¿a qué nos referimos cuando usamos la palabra "memoria" en el campo del patrimonio? ¿Cómo se cruza el abismo que separa sus dimensiones social e individual? Este artículo teoriza sobre la íntima relación entre patrimonio y memoria, centrándose en tres áreas. La primera cartografía el vocabulario generado por la díada patrimonio-memoria, incluido el uso $-\mathrm{y}$ a veces el abuso- que se ha hecho de las nociones de memoria colectiva y lieux de mémoire, así como las metáforas empleadas en ese proceso. La segunda aborda la aparición de los estudios de la memoria, ofreciendo una breve panorámica de sus fundamentos y evaluando en qué se diferencian, se complementan o contribuyen a la investigación sobre el patrimonio. Y por último se revisan brevemente los últimos avances de la psicología cognitiva, la neurociencia y la biología evolucionista relacionados con la memoria y su posible influencia en los estudios del patrimonio. En la conclusión final se sintetiza la contribución teórica y empírica de la investigación de la memoria a una mayor comprensión del patrimonio cultural y se indican vías para el trabajo futuro sobre la esfera de confluencia entre los dos.

PALABRAS CLAVE: Patrimonio cultural; memoria; memoria cultural; neurociencia; memes; lieux de mémoire; psicología cognitiva.

Copyright: (C) 2015 CSIC This is an open-access article distributed under the terms of the Creative Commons AttributionNon Commercial (by-nc) Spain 3.0 License. 
There are days that might outmeasure years, days that obliterate the past, and make the future, of the colour which they cast. (Inscription on a funerary monument, Père Lachaise cemetery, Paris, 1856)

Over the past two decades the ways in which we look at cultural heritage have evolved dramatically from monument and museum collection to encompassing a complex matrix of meaning, values, associations and related concepts. As a result of this conceptual evolution, cultural heritage has gone from being understood as property, an object, to being assessed as a process; passing through several intermediary and frequently simultaneous understandings such as place, product, project, and performance. The outer boundaries of the concept are still subject to experimentation, pushed to test the limits of how far the idea can be expanded before collapsing into an undifferentiated state where 'everything is heritage'. We are thus now at a moment when it has become necessary to fully (re)engage with the complex theoretical dimensions of cultural heritage and its multifaceted ramifications.

In approaching this rich theoretical evolution, various threads of its definition, dynamics, and functions have been teased out of a knotted bundle. Not surprisingly given the diverse ways in which heritage can be contemplated, it is increasingly being approached as an assemblage that includes material and immaterial forms: representations and aspirations, mortar and emotions, values and interpretations, symbols and narratives. One crucial component of this assemblage is memory: without the notion of memory and everything that it suggests about time and narrative, continuity and change, individual and collective identifications, heritage would be reduced to 'old things'. Because of the centrality of memory to heritage, the association of these two terms is recurrent in heritage literature and yet it often takes for granted a rather 'thick' relationship between two complex and fluid concepts. Furthermore, even as heritage researchers have been progressing towards ever more nuanced understandings of the concept, so too has the understanding of memory been expanding in myriad ways. For, while the field of heritage has been establishing its theoretical and methodological basis - a process to which ideas about collective memory and sites of memory have been so influential - two parallel developments have been following their own courses: memory has emerged as a field of study in the humanities and social sciences, and research in cognitive psychology and neuroscience has made important advances in revealing how memory works within the brain.

Some authors have dealt explicitly with issues of memory in relation to heritage (e.g. Lowenthal, 1996; Elsner, 2003; de Jong \& Rowlands, 2007; Benton, 2010) but generally the dyad has been taken for granted. This assumption arises in part because memory seems so integral to our sense of knowing the past and of interpreting its remains, and in part because of the roles played by two other concepts - identity and politics — not only in mem- ory and heritage independently but more crucially in binding the two together.

The description of John Soane's museum as "treasures salvaged from a shipwrecked dream" (Woodward, 2002: 160) could well be applied to some approaches to both cultural heritage and memory: cultural heritage as the ruinous remains of past creations, memories as the imperfect remains of past experiences. These approaches taint both ideas with nostalgia for a past that is irretrievably lost, leaving wide gaps to be filled. And while they have been immensely influential in shaping the development of museums and mnemonics they also significantly limit a full appreciation of the complex web of dynamics at work in heritage and memory, resembling too closely the monumental and antiquarian approaches to history criticized by Nietzsche $(1974,1980)$.

The contemporary field of memory studies has many disciplinary tributaries that feed into it and use the word 'memory' to refer to a slightly different aspect of the phenomena, each with its own associations and theoretical frameworks. Holocaust studies, literary theory, sociology, psychoanalysis, political science, cultural history, theology, anthropology, and archaeology all use the term though they do not necessarily mean the same thing by it. This rich cross-fertilization comes with a danger that findings from neighbouring disciplines are adopted without a careful assessment of whether the shared vocabulary actually has shared semantics behind it or if the same words are being used to refer to different phenomena. This is not to say that interdisciplinary research should not be carried out, only that borrowing terms across fields should be enunciated and the interpretations, departures, or translations made explicit. Thus, when referring to some of the kinds of memory from the 256 identified by Tulving (2007) — such as iconic, place, or recall memory - it would be helpful to indicate just how the term is being used, whether according to a cognitive neuroscience understanding that rests on a specific body of theoretical and empirical work, or according to an adaptation of the term in order to use it as a tool in thinking about dynamics observed in the heritage field.

Exploring the relationship between cultural heritage and memory - and identity with which they are both closely linked - unavoidably throws up a question of scale (Isar, Viejo-Rose \& Anheier, 2011:1-18). For while heritage and memory are engaged at the most personal level of an individual's construction of self they also firmly intertwine it with society through an ever-expanding, and constantly re-negotiated, connectivity of relationships between the self and the world. As a tangible manifestation of a form of memory, cultural heritage is ceaselessly passing back and forth between different scales: from what has been directly inherited from one's own family, to that which remains of a group of people who lived hundreds of years ago. And this question of scale is also at the heart of the heritage-memory relationship. The path of the collective leads most obviously to sociology, social psychology, history, literature, culture studies, and today, memory studies. Traditionally, going down the 
path of the individual leads to cognitive psychology, psychoanalysis, and neuroscience and the light that these disciplines might be able to shed on the workings of memory. Yet, these two broad approaches need not necessarily be divided so absolutely; if we bring the disciplines into conversation the cross-over might reveal new insights. This paper will proceed to examine both memory studies and neuroscience to see how they can help to see the dyad more clearly.

This paper theorizes the intimate relationship between heritage and memory focusing on three areas; it does not make one argument but seeks to indicate various dimensions of this relationship that could open up new avenues for critical thinking about cultural heritage. First, it maps out the vocabulary that has emerged from the heritagememory dyad; this includes discussion of how notions of collective memory and sites of memory have been used, and occasionally misused, as well as the metaphors employed in the process. Second, the emergence of memory studies is considered, providing a brief overview of its foundations and aims as well as assessing how it differs from, overlaps with, and contributes to heritage research. A third section offers a brief review of recent developments in cognitive psychology and neuroscience, and evolutionary biology relating to memory and how these might inform heritage studies. The concluding discussion provides a synthesis of the theoretical and empirical contribution of memory research to furthering our understanding of cultural heritage and proposes directions for future work on the area of confluence between the two.

\section{MAPPING THE LEXICON OF AN INTERSECTION: OVERVIEW OF VOCABULARY AND CONCEPTS}

The word 'heritage' often evokes the notion of inheritance that, unlike 'heritage', has the advantage of coming in the form of verb, adjective, and noun, thereby imbuing it with the sense that it is a process and qualifier as well as an object. This flexibility reflects the current understanding of heritage as process: "... heritage is not lost and found, stolen and reclaimed. It is a mode of cultural production in the present that has recourse to the past" (Kirshenblatt-Gimblett, 1995: 370; see also Smith, 2006). Consequently, attempts have been made to break the con- fines of the word 'heritage' in order to reflect its action potential, 'heritagize', and its plurality, 'heritages.' The contemporary exploration of the conceptual boundaries of cultural heritage has thus been accompanied by a burgeoning of the vocabulary that we use to talk about it. The emergent terminology includes new expressions like 'authorized heritage discourse' (Smith, 2006), and new composites such as heritagescape (Garden, 2006: 394411; Viejo-Rose, 2011: 11-12, 219), or has involved the addition of qualifiers as in 'dissonant heritage' (Ashworth \& Tunbridge, 1996). When exploring in particular the relationship between heritage and memory there are terms that have been borrowed from other fields, occasionally being turned on their heads, such as psychology's 'event memory' being converted to 'memory event' by researchers in the humanities (see Etkind, 2010). Yet other terms have been translated — such as lieu de mémoire- spurring a flourish of interpretations that depart from the original meaning. There are also words from other disciplines that call out to be explored, adopted, and perhaps adapted to the heritage lexicon, as will be seen in the section on neuroscience. Lastly, there is the tendency to rely on metaphor (See Table 1).

One way of mapping the heritage-memory lexicon would be to list kinds-of-memory and kinds-of-heritage and, Venn-diagram-like, identify the terms falling in the overlapping area. This task begins to take on intimidating proportions however, when one considers the ' 256 kinds of memory' identified by Tulving (2007) as used in psychology and neuroscience, and when one adds to this the terms used in history, anthropology, sociology and other disciplines. Furthermore, by the time this article appears the kinds of heritage — and therefore also possibly the overlapping area between the two fields - will no doubt have augmented. For, in the humanities, work on the role and manifestations of memory has given rise to an array of terms that to varying degrees relate directly to heritage such as: mémoire trouée (Raczymow, 1979), absent memory (Fine, 1988), lieux de mémoire (Nora, 1984-1992), inherited memory (Lury, 1998), narrative memory (Ball, 1999), prosthetic memory (Landsberg, 2004), historic memory, memory boom (Doss, 2008), postmemory (Hirsch, 2008). There are memory parks, memory politics, memory wars, and memory studies.

TABLE 1: Metaphors we use to think about the heritage-memory relationship.

\begin{tabular}{|l|}
\hline Heritage as a... \\
memory trigger \\
memory container/storage \\
memory communicator \\
spatial marker of memory (i.e. landmark or signpost) \\
narrative marker of memory (i.e. reminding of key moments, characters, and events) \\
anchor for memory (fixing it to a place and time) \\
transmitter of processual memory (know-how) \\
collection, or cache of memories \\
site of memory (place where commemorations are rehearsed and performed)
\end{tabular}


MEMORY(IES) AND HERITAGE(S): INDIVIDUAL AND COLLECTIVE/SINGULAR AND PLURAL

Possibly the hairiest question that the relationship between memory and heritage gives rise to is that of individual versus collective understandings. The appropriateness of the leap from individual to social memory has been questioned by authors who see in this move a 'metaphoric extension' (Radstone and Hodgkin, 2003: 8), a necessary metaphorizing of the idea of memory, in particular when the leap is accompanied by a collage of terminology from various fields such as archaeology, history, sociology, and phycology (on the 'borrowing of terminology' see Erll, 2011: 96-97; Burke \& Faulkner, 2010: 1-2). When it comes to collective memory and cultural heritage however, it becomes difficult to untangle the two. Heritage, like memory, is experienced and perceived, or to use the neurological term 'inputted', at the level of the individual, through the senses. And yet it is only through social interaction - whether at familial, national or 'world' level — that heritage fully comes into its own. For, it is in the process of concretising and communicating that values, protagonists, plots, and narratives are appended to heritage. Despite the closeness of the relationship, it is problematic to bind collective memory and heritage together as though the latter were a representation and/or deliberately selected materialisation of the former: the links are not as straight forward as they might initially appear. In analysing those links, it is helpful to refer to research that has focused on differentiating between the individual cognitive level of memory and the collective social level (i.e. Wertsch, 2002; Esposito, 2008; Assmann, 2004; Olick, 1999; Olick, Vinitzky-Seroussi \& Levy, 2011). I argue that this line of questioning is basic for thinking about heritage.

\section{HERITAGE STUDIES AND MEMORY STUDIES: SIMILARITIES, OVERLAPS AND DIFFERENCES}

The study of memory has a heritage of its own, a repertoire resulting from the work of artists, scientists, and theoreticians who have specifically addressed the issue. Many artists have tackled the issue of memory - William Wordsworth, Emily Dickinson, and T.S. Eliot, Marcel Proust, Jorge Luis Borges, and Milan Kundera, Louise Bourgeois, Robert Rauschenberg, Anselm Kiefer, Christian Boltanski, and Marina Abramović, to name just a few. And their works, their poetic, fictional, and visual treatment of memory, have in turn been drawn on by scientists for inspiration, and been the subject of extensive critical analysis. Then there is the genealogy of the concept itself. Our contemporary and speedily evolving understanding of memory has several influential recent ancestors, however here one sees how disciplinary boundaries have often meant that these are not necessarily shared. Rather, each discipline has its own lineage, with some crossover. While it would be possible to trace the first recorded concerns with memory and its functions back many centuries, the origins of contemporary thinking start with Hermann Ebb- inghaus and Henri Bergson at the end of the nineteenth century, followed by Frederic Bartlett and Maurice Halbwachs in the $1930 \mathrm{~s}^{2}$ unsurprisingly perhaps the disciplinary basis for these enquiries are psychology, sociology and philosophy. Ebbinghaus' (1885/1964) work on memory sought to discover from the perspective of psychology whether there were any general laws of memory; through experiments on learning he initiated a taxonomy of memory (Rose, 2010: 199-200). Bergson's Matter and Memory (1896/1991) offered a philosophical exploration of memory that hugely influenced French and German theorists such as Paul Ricoeur and Walter Benjamin.

It is not coincidental that a keen interest in collective experiences and how they are communicated and shared through narration and memory came to the fore in the aftermath of the First World War. Frederic Bartlett and Maurice Halbwachs both published works in the 1930s that emphasised the function of remembering in social contexts as a means of sharing impressions and, at least for Halbwachs, of reinforcing the narratives of adhesion to a group. The three writers whose work is consistently referred to in heritage literature that addresses memory are Maurice Halbwachs, Paul Ricoeur, and Pierre Nora.

Halbwachs' work on the social frameworks of memory $(1925 / 1994)$ and collective memory $(1950 / 1980,1992)$ is frequently referenced in heritage literature though often it is done in order to adopt, and adapt, the term rather than through a reflective reading. Other than serving as timber to stoke the fires of the argument about whether collective memory exists or is purely a metaphor, Halbwachs' work remains a rich source of inspiration for thinking about cultural heritage. His work on the relation between memory and materiality, especially space and physical surroundings, is particularly relevant today as the scope of heritage continues to expand from sites to 'scapes' (e.g. landscapes to heritagescapes). As he writes: "If a truth is to be settled in the memory of a group it needs to be presented in the concrete form of an event, of a personality or a locality" (Halbwachs, 1992: 200). Paul Ricoeur's History, Memory, Forgetting (2000/2004) is another key text that will be cited throughout this piece in part because of its important insights and also because of its influence on other theorists. Yet it is Nora's work that has had widespread impact on ways of seeing and thinking about heritage.

The concept of a lieu de mémoire is frequently lost in translation. The term is used to refer to anything from places where remembered events have occurred to memorial sites, including a wide spectrum of other interpretations in between; what they have in common is an emphasis on physical sites when precisely the point of the large collective work directed by Nora was to reveal the intangible, symbolic, and cognitive reference points that serve to bind together a group, and more specifically, a Nation. Nora presents the work as an exploration of the dynamics between history and memory in terms of the repertoire of reference points that emerges at their intersection to create a sense of shared national past. In this sense it can be understood as stemming from Benedict 
Anderson's (1983) work on 'imagined communities' in which he posited that the three constructive elements of the sense of a national collective were the census, the map, and the museum. It can also be seen to relate to Roland Barthes' concept of the 'modern myth' (1973/1957). For both Anderson and Nora, the object of focus at which they were pointing their theoretical microscopes was the Nation; a determining aspect of these lieux often overlooked. In addition, uses of the term that reinterpret it frequently do not include caveats explaining the departure from its original meaning, thus giving rise not only to a significant diversity of meanings associated with the term but also, unfortunately, much muddling of it. What is bemoaned here is not that this has led to a vast array of interpretations, but the absence of clear statements of intent and definition that result in confusing rather than clarifying the theoretical ground. When interpretations inspired by the original are explicitly laid out, the resulting work broadens understanding by adding facets to it - for instance Jay Winter's work which, taking inspiration from Nora deliberately defines 'sites of memory' more narrowly "to mean physical sites where commemorative acts take place" (Winter, 2010: 312, see also Winter, 1999). Even a cursory look at the essays in the seven volumes of Les Lieux de Mémoire (1984-1992), Realms of Memory in the abbreviated English volumes edited by Kritzman (1996-1998), puts in evidence an understanding of these lieux as crystallizations of memory but not necessarily physical sites - they include songs, heroic figures, recipes, literary texts and many more. What makes the work directed by Nora so relevant for theorizing heritage is that the project was in large part an exploration of the relationship between memory and history. Within the oppositional mode that he sets up to explore this relationship heritage seems to sit at the juncture between the two, for example when he writes that: "Memory takes root in the concrete, in space, gestures, images, and objects; history binds itself strictly to temporal continuities, to progressions and to relations between things" (Nora, 1989: 9). For heritage does the former in order to do the latter - thus giving rise to one of the numerous dichotomies of the heritage concept which is the tension inherent in its function as engenderer of both roots and routes ${ }^{3}$.

Paradoxically, what has been termed as today's 'memory boom' (Huyssen, 1995; Winter, 2000), or 'era of memory' (Hoffman, 2004: 203) originated in a theoretical moment in the 1980 s that posited social amnesia as the defining characteristic of contemporary society (Radstone \& Schwartz, 2010: 1-4). It was this preoccupation with what appeared to be a widespread trend of forgetting, of rupture with the past and an obsession with experiencing the present, which led to the focus on memory and the emergence of memory studies, and had a transformative effect on ways of seeing heritage. This section outlines the common ground and differences between heritage and memory studies.

There are at least three core areas in which the study of memory and heritage overlap in terms of common in- terests and concerns. Firstly they both - "draw[s] on a range of disciplinary traditions to examine the forms and functions of representing the past" (Roediger \& Wertsch, 2008: 9). This definition of the field of memory studies will also ring true to those working on heritage. Frequently the term 'cultural memory studies' is used (Erll, 2011:2) and consists of a similarly varied disciplinary constellation that includes oral history, popular culture, monuments, memorial acts, public discourse about the past, and autobiographical writing; fields that heritage studies also often draws on. Finally, both fields are intimately linked with politics as in 'the politics of memory' or heritage (Isar, Viejo-Rose; Anheier, 2011:10-11). These three areas — past, culture, and politics - are shared interests of the two fields of study, with a fourth, identity, also worth highlighting. For the role of both memory and heritage in the construction and perception of identity, and the politicization of this role, is a key concern for both fields. The exercise of outlining a common terrain is useful in that it helps to pin-point the knotty issues that the two fields can work together in tackling, for there is clearly a ground for mutual feed-back between memory and heritage studies.

One example of a knotty issue shared by the two fields is that of nostalgia and its dangerously warping effects on our construction of the past: "And at a time of erasing one memory and constructing a new one - that is, at a time of enforced amnesia and enforced remembrance - every nostalgia, even the most harmless, is, rightly, considered dangerous" (Ugresić, 1996: 32). A further area that has been of growing concern for both fields and whose elucidation might benefit from a collaborative approach is that of commemoration, including practices of memorialization and the mediatisation of memory more generally. The historian Eric Hobsbawm writes on restored or invented tradition that it refers to a "set of practices normally governed by overtly or tacitly accepted rules and of a ritual of symbolic nature which seeks to inculcate certain values and norms of behaviour by repetition which automatically implies continuity with the past" (Hobsbawm \& Ranger, 1983: 1). Memory becomes the narrative binding these practices such that they are accepted as tradition, while the props (monuments and artefacts), stage-settings (buildings and sites), and performances (dances and recitals) communicating the narrative are what many would recognise as heritage.

At the crossroads where heritage and memory meet lies the inescapable dualism of the tangible and intangible dimensions of the former. In 1992 UNESCO established the 'Memory of the World Programme' in an effort to preserve archival and oral histories and enhance access to them. The resources created to these ends include a 'Memory of the World Register' that is a list of documentary heritage inscribed therein, and 'Memory of the World Photos'. The translation of a programme on something as ambitious as preserving the world's memory into an archiving and documentation project illustrates the difficulties of translating the intangible and the abstract, the fluid and malleable, into some-'thing', a materiality that is 
physically preservable (even when it relies on the virtuality of digital and on-line technology). This too is a common shortfall in attempts to protect and preserve heritage.

While there are important common areas of interest, and a clear symbiosis, memory and heritage are not, synonyms and neither their theoretical foundations nor methodological tools map onto each other completely. Wilson indicates that: "[...] the value of memory studies to the analysis of heritage rests in the acknowledgement that memory is constructed purposefully through cultural forms with significant social and cultural consequences" (Wilson, 2009: 378). Heritage sites and objects are often seen as 'memory caches' (Sørensen, 1996: 24-25). Accordingly, what heritage studies can contribute to the analysis of memory is a critical awareness concerning the translation of memory narratives into various forms of expression both tangible and intangible, including the political uses of these manifestations of 'pastness' that are continually being constructed and revised.

Thus far, one of the most diacritical aspects between the two fields of study has been the way each approaches the relationship between medium and memory ${ }^{4}$ which is in turn reflected in a different choice of empirical focus. For while memory studies has often taken as its primary object of study discursive and visual representations (works of literature, film, media portrayals, and autobiographical writing), heritage research has more often adopted a case-study approach focusing more on non-discursive phenomena and on particular sites (monuments and museums), landscapes, urban areas, and, more recently, practices and performances. Again there are overlaps - such as the analysis of museums and memorial practices or the use of oral history - but each field applies its own analytic lens constructed out of its own combination of theoretical and methodological lenses.

It would be tempting to signal experience as a clear distinguishing boundary between memory and heritage: that memory is tied to experience whether lived in the first person or learned from another, while heritage is tied to values and a process of meaning-making that identifies the signifiers of those values in sites, tangible or otherwise. Remembrance of past experience, however, is highly susceptible to being altered by interpretation and even fantasy (Barash, 2011: 253-5). Since memory (even from the perspective of cognitive neuroscience, as we will see further on) is increasingly understood as a process of constant construction, it might be prudent to handle this apparently straight-forward differentiation with a healthy dose of scepticism.

\section{The ethics and politics of memory (its materialization in memorial policies)}

Radstone (2008: 32) argues that within memory studies concerns with the ethics of memory have dominated, and often obscured, the politics of memory. She attributes this to a dominant focus from the humanities and social sciences side of memory studies on the aftermaths of conflict, trauma, catastrophe, and, by extension, on witnessing. Cer- tainly, an important body of work examining the relationship between heritage and memory has taken as its empirical focus the study of cataclysmic events, most frequently in the shape of war or natural disasters. (See for example Antze and Lambeck, 1996; Bevan, 2006; Hoffman \& Oliver-Smith, 2002; Viejo-Rose, 2011). This, however, would indicate not an either/or situation - ethics or politics - but rather corroborates something that Ricoeur already stressed in his work on memory and forgetting: that memory is both a kind of knowledge and a form of action. The implications of the latter understanding in particular are vast for the practices, policies, and politics of heritage. Ricoeur writes: "It is because memory is an exercise that we can talk of the use which in turn permits us to talk about the abuses of memory" (Ricoeur, 2004: 5). Studying how traumatic events are publicly remembered has become just such a focus because it brings to light the ethical and political, the uses and abuses, of both social memory and heritage. While not directly writing about heritage, in her exploration of postmemory Marianne Hirsch writes: "(...) those of us working on memory and transmission have argued over the ethics and the aesthetics of remembrance in the aftermath of catastrophe" (Hirsch, 2008: 104). For her, the urgency lies in the questions that this form of remembrance provokes in relation to duties towards victims, the responsibilities that come with witnessing suffering, and the potential of memorial practices to drive changes in society that will make it less violent.

Catastrophic events traumatise and transform to the extent that they become signposts in individual and collective memory narratives. (Hoffman \& Oliver-Smith, 2002) The process of politicising the past goes right to the heart of heritage and it has as much to do with remembering as with forgetting. In discussions of collective forgetting, or oblivion (Augé, 2004), it is often the editing out of the past, deliberately choosing to remember certain events - those that strengthen the historical narrative of continuity and myths about origins - that is the focus of many studies. In his exploration of forgetting, for instance, Connerton writes:

Newly shared memories are constructed because a new set of memories are frequently accompanied by a set of tacitly shared silences. Many small acts of forgetting that silences enable over time are not random but patterned... (Connerton, 2008: 63. For a discussion of spaces of memory and forgetting see also Legg, 2007 and Owain \& Garde-Hansen, 2012).

Unsurprisingly, memorial practice is an area of overlapping interest to heritage and memory studies. Nevertheless, what is perhaps less obvious is that it is not only the aftermath of violence but also the act of destruction itself that has stimulated a conjoined approach. This is evident in the titles of works such as: "Iconoclasm and the preservation of memory" (Elsner, 2003); "The Destruction of Memory: Architecture at War" (Bevan, 2006); "Reconstructing Spain: Cultural Heritage and Memory after Civil War" (Viejo-Rose, 2011). 
Radstone and Schwartz challenge positions which posit that the rise of interest in memory is a symptom of its atrophy; instead they suggest " (...) to start from a contrary premise: not that memory is no longer possible, but rather that we are witnessing an unprecedented politicisation of memory" (Radstone \& Schwartz, 2010: 4). When the politics of memory involves the representation of traumatic events, forms of both symbolic capital and moralising narratives can be generated; the reinforcing impact of mourning rituals, memorial actions, commemorative monuments and repeated retelling of accounts of suffering and survival have the effect of both destroying and generating heritage. At the origins of the recent expansion in understanding of heritage was precisely a concern with its politics, its uses and abuses (for instance Lowenthal, 1996). The most important aspect though is something that Hobsbawm called attention to when he warned against current trends in the mythologisation of history, especially by politicians:

one of the things that tended to get lost is the sense of difference, which is basic, between fact and fiction. Between what actually happened, and that there was something that actually happened, and either what didn't happen or what we would have liked to have happened (Hobsbawm interviewed by Schama, 2012).

Recent attempts by politicians to explicitly control social memory has lead to an "ideological policing of cultural memory" (Burke and Faulkner, 2010: 9). This has included legislating over history —what historians can or cannot claim, what school curricula must include, and the sanctions for anyone straying - , and has given rise to the movement 'Liberty for History' and provoked this group of historians to produce the Appel de Blois denouncing attempts by political authorities to establish historical truth, arguing against memory laws and calling for an end to the "memory police" (Garton Ash, 2008: 24). The relevance of all these debates to heritage should be clear: as a field occasionally defined as 'the politics of the past', the role of heritage management and policies in upholding or undermining imposed memorial or historical narratives is critical. Not coincidentally, laws, publications, media focus, public discourses, and research projects exploring 'historic memory', 'memory wars', and the 'social practices of memory' have all zeroed in on heritage sites to illustrate or back up arguments and as themes for study.

To synthesize and conclude this section, Memory Studies and Heritage Studies share some common ground conceptually an in the material that they use however, they vary in that they each draw on a different, though occasionally overlapping, set of theoretical and methodological tools and in that they each orient their gaze differently in the pursuit of distinct questions. While Memory Studies has thus far largely used critical theory and literary analysis, informed by culture studies and historiography, to explore how memory is narrated in a wide variety of forms and formats, heritage has used tools from ar- chaeology, anthropology, and museum studies to explore the meanings of materiality, the values projected onto it, and how it is preserved and presented. One clear area of overlap thus far has been the process of memorialisation and commemoration where memory narratives are performed and materialized in various ways. Furthermore, as heritage studies have progressively expanded to include various intangible, or immaterial, forms the area of overlapping interests has increased. This does not mean that the two areas coincide entirely, for the questions that drive each area are notably different in nature. It will be exciting to see how collaboration across the two areas of study might stimulate the emergence of new questions and understanding.

\section{MEMORY ON THE BRAIN: HOW THE NEUROSCIENCE OF MEMORY CAN INSPIRE NEW AVENUES FOR THEORIZING HERITAGE}

In his essay entitled 'Are there 256 Kinds of Memory?' Tulving writes: "In the old days, there was only one kind of memory. To study memory meant to study that one kind. Then things changed, and among other changes there appeared on the scene different kinds of memory" (Tulving, 2007: 40). Though it should be noted that in the 'old days' St. Augustine had already listed a variety of memories. In an appendix to his essay Tulving lists the 256 kinds of memory that he has recorded, usually created by pre- or post-modifying the noun. It is somewhat alarming that his long inventory does not include those terms used in heritage and memory studies today alarming because it would grow significantly. While there might not be an exactly corresponding list of 256 kinds of memory used in humanities disciplines, it is curious to note that memory's imperfections have been classified as "seven categories or 'sins"" (Schacter, 2001) by a neuroscientist and as "seven types of forgetting" (Connerton, 2008) by an anthropologist ${ }^{5}$ (See Table 2). The flourishing of research on memory in the humanities has evolved in parallel to what has been described as "a revolution in our understanding of memory" (Squire \& Kandel, 1999: ix) in the sciences.

The study of memory's functioning in brain and mind is a subject that engages many branches of science. Squire and Kandel (1999) describe the latter as having evolved along two paths: the biological and the psychological. The first has focused largely on asking where memory lies in the brain, the mechanics of how nerve cells communicate and store experience thus leaving a record, trace, in the brain. Many experiments have tried to track the 'electrical circuits' of memory (e.g. Kandel). The second, focusing on cognition has sought to discover how memory works, mapping the diverse paths that it follows in the brain and asking what forms memory comes in. Squire and Kandel, by joining the two approaches sought to create a "bridge from molecules to mind, that is, from molecules to cells, to brain systems, and to behaviour" (Squire \& Kandel, 1999: 3). Radstone and Hodgkin have written about their concern that the metaphoric extension 
TABLE 2: Memory's failings.

\begin{tabular}{|l|l|}
\hline $\begin{array}{l}\text { "seven types of forgetting" a view fro sociology } \\
\text { (Connerton 2008) }\end{array}$ & $\begin{array}{l}\text { "seven sins of memory" a view from neuroscience } \\
\text { (Schacter 2001) }\end{array}$ \\
\hline repressive erasure & transience \\
prescriptive forgetting & absent-mindedness \\
forgetting that is constitutive in forming a new identity & blocking \\
structural amnesia & misatribution \\
forgetting as annulment & suggestibility \\
forgetting as planned obsolescence & bias \\
forgetting as humiliated silence & persistence \\
\hline
\end{tabular}

that they see lying at the heart of the move from individual to collective memory has been so effective that policy has been "built on that metaphor" (Radstone \& Hodgkin, 2003: 8). If we consider behaviour to be a social rather than individual phenomenon, then what the cognitive sciences are showing is that the brain's processing of memory is at the root of that move. This suggests that there is more than a 'metaphoric extension' at the junctures between brain and mind, between self and society. It can be immensely inspiring for thinking about cultural heritage to look into cognitive understanding of memory's functioning; while the inspiration will occasionally be metaphorical there are also areas where the disciplines can compare notes, learn from one another, and in collaboration further 'thicken' our understanding.

The foregoing has indicated some surprising parallels in how the social sciences and neuroscience approach memory in ways that can inspire thinking about heritage, and there are more. For example, among the types of memory identified in the cognitive sciences are two large categories: procedural and declarative (there are others including working memory and reference memory, shortterm versus long-term memory). Most theorizing of heritage has focused on the second because the act of preserving a site through policies on conservation practices is a form of declarative memory, a statement of memory: 'we remember the value and meaning of this and so decide to preserve it'. Making this link more relevant still is that declarative memory is further divided into semantic memory, which refers to a symbolic knowledge of the world, and episodic, or autobiographical, memory that refers to a memory of past events. The parallel is clear: analyses of cultural heritage have looked both at its role as a signifier and information store, and as a reminder of past events. The procedural dimension has begun to gain ground in heritage studies more recently as work on intangible heritage has progressed, for here it is precisely the 'know-how' that is important, the process of doing, learning, and transmitting rather than the finished product. Cultural memory too has made a comparable distinction with the terms functional memory and stored memory (see Erll, 2011: 34-37 citing Assmann \& Assmann, 1994). These distinctions all indicate a difference between implicit and explicit memory. The importance for developing theoretical tools with which to study memory dynamics in heritage processes is precisely that there are both explicit and implicit ones, but thus far heritage studies has often focused on the first and taken the second for granted.

Before memory comes experience, and experience enters through the senses. A lot of the work done in cognitive neuroscience so far has focused on visual pathways, but work on other senses seems to show similar mechanisms by which the brain "integrates sensory data into a perceptual experience" (Mishkin \& Appenzeller, 1987: 82; also see Squire \& Kandel, 1999). In the foregoing section on memory studies, the driving role of interest and research, on how traumatic events, violence, and loss are remembered, was raised. In the sciences there has also been an interest in how traumatic events are remembered, partly out of concern for the mental and emotional health of individuals and partly to understand the reliability, and fallibility of witnesses when recounting their memories of events at trials. What this research shows is that individuals tend to remember the 'meaning' of events rather than details (Schacter \& Addis, 2007), and that when faced with an intense emotional situation dynamics kick in that shape subsequent memory consolidation (LeDoux, 2002; Chen, 2012). Heightened emotions trigger all sorts of reactions that determine how memories are constructed, stored, reconstructed, and retrieved, three examples being: flashbulb memories, that actually fade and distort though they continue to seem vivid and factual; tunnel memory, that focuses on the central event such that surrounding details are forgotten; and cognitive reappraisal, favouring the positive dimensions of a negative situation (Chen, 2012). These insights could be tremendously revealing for our understanding of memorial processes and how traumatic events are commemorated, and so also for the study of heritage creation in response to traumatic/violent events.

A field of research in cognitive neuroscience that is hugely suggestive for heritage work is that which looks at engrams or memory traces; this refers to how memories are encoded in terms of changed synaptic connections, which in turn means how the brain changes physiologically (biochemically) based on how it is used, in this case for remembering. This change is explained in Hebb' s (1949: 62) rule: “when an axon of cell A is near enough to excite a cell $\mathrm{B}$ and repeatedly or persistently 
takes part in firing it, some growth process or metabolic change takes place in one or both cells such that A's efficiency, as one of the cells firing B, is increased". Further complicating the picture, and making it more interesting is that "memory traces apparently firmly located in one brain region seem over the subsequent hours and days to migrate to others" (Rose, 2010: 206). There are clear metaphoric parallels for heritage here and perhaps with more research the use of metaphors, itself a form of thought, will open up new insights into the heritage process as well.

What is particularly striking about the two lists of failings of memory identified above is that those related to social memory are for the most part couched in a negative light, implying at best a conscious deliberate selection of what to forget and at worst the abuse of force to impose forgetting, while the processes identified by Schacter are unconscious, deliberate forgetting is accepted as an act of memory (See the work of Michael Anderson at the Cambridge Brain Unit, Garcia-Bajos et al., 2009; Levy \& Anderson, 2008). This significant difference between the two lists begs the question of whether deliberately forgetting is not in itself an act of memory, and therefore of how successful policies of imposed forgetting might be. Might it not be when forgetting becomes 'naturalized' and therefore unconscious that it is truly successful and erasure complete? But this question introduces another area of research into emotional memory and Joseph LeDoux's $(2000,2002)$ studies that suggest that memories linked by learned responses to particularly strong sensorial stimuli - i.e. an electric shock inducing a fear response - mark the brain permanently.

LeDoux's putative circuit models how an emotional stimulus is processed by the brain through channels that - passing through the sensory cortex, the perirhinal cortex and the hippocampus - centralise in the amygdala, which in turn sends out messages to those parts of the brain that react to the stimulus. ${ }^{6}$ Despite recent critiques remarking that this circuit does not show the full picture - that other areas of the brain are involved and this particular model works for fear conditioning in particular but not necessarily for the handling of all emotional stimuliit is still an interesting basis from which to think about the various networks at work in processing cultural heritage stimuli, and the variety of reactions that these provoke. After all, associational hooks tether meanings to sites in large part by making them emotionally resonant. Thus, an interesting point of juncture in the research here would be to bring together this work on emotional memory with that being done within heritage studies on the commemoration of traumatic events, and how the memory of fear and loss is socially transmitted.

Another potentially rewarding example where advances in neuroscience might help to think about heritage is in work on how spatial memory is recorded and called upon. Eleanor Maguire's studies of London taxi drivers -who were asked to recall complex journeys within the city while being monitored under functional magnetic resonance imaging (fMRI) - suggest some seductive in- sights, and questions, for thinking about the effect of visiting heritage sites versus learning about them. For example: how might the processing and sense of ownership of heritage differ among a repeat visitor to a site such as the British Museum, a one time visitor, and a virtual visitor? Experiments in cognitive neuroscience appear to show that in order for memory to be stored in the long-term a successful consolidation is required and this involves a process of rehearsal. Heritage studies are very familiar with the rehearsal and performance of memory in many forms, from re-enactments to memorial services, television dramas based on historical settings to documentaries about historical events.

A final potentially fruitful area for crossover thinking and research relates to evolutionary biology. The mid 1990s, and especially 1996, seem in retrospect to have marked the beginning of a new phase in thinking about memory. Lowenthal's reflections on the spoils of history and the first translated volume of Nora's Realms of Memory came out; in addition New Formations dedicated a special number to 'cultural memory'. An important innovation from these years that offers a further area of possible crossover thinking and research that remains undeveloped by heritage researchers, despite its potential as a conceptual tool for illuminating the memory dynamics at the heart of heritage, is the meme. A concept developed by Daniel Dennett (1991, 1995), Richard Dawkins (1993), Richard Brodie (1996), Aaron Lynch (1996), and Susan Blackmore (1999), the meme is defined by the Oxford English Dictionary as "An element of a culture that may be considered to be passed on by non-genetic means, esp. Imitation" (See Dawkins in Blackmore, 1999: viii). The role of heritage in transmitting memes as well as myths is an area of study that would help to elucidate the interplay between it and forms of social memory.

The most basic level of defining memory is the capacity of something to retain inputted information and transform it such that it can be outputted, communicated or manifested externaly (Squire \& Kandel, 1999: x). Following this basic understanding, not only blackboards and computers have memory but also artefacts and monuments. Memory then, even at its most basic, is a factor of heritage, at its most basic. Moving from this basic level however, the most evident meeting ground for the two concepts is time - the pastness of time, the ability of individuals and groups to have a sense of past time and traces of that past whether in the form of retrievable information or physical remains. The role of memory in perceiving, even containing, time was a knot that St Augustine addressed arguing for the predominance of the present: 'a present of things past, a present of things present, and a present of things to come' (Augustine 1991/400). The first of these is remembering what has gone, the second about sensing what is immediately present, and the third involves formulating expectations about the future (Wetzel, 1995: 346). What recent research in cognitive neuroscience shows (Schacter \& Addis, 2007) is that these three are bound together in a circuit. 


\section{SYNTHESIS AND WAYS FORWARD}

\section{A symbiotic relationship?}

The neuroscientist Eric Kandel's autobiographical book In Search of Memory (2006) swings between accounts of his scientific experiments on the imprinting of memory in the Aplysia, a giant marine snail, for which he won the Nobel Prize in Physiology or Medicine, and his childhood memories of Vienna in the 1930s, including fleeing in 1939. That a scientist who has dedicated his life to studying memory should write an autobiography, and in so doing combine an account of scientific experiments to understand memory at the level of axons with personal memories of a tumultuous childhood during a turbulent historical period is a powerful statement of how tightly woven the different strands of memory are. For they merge the neurological, tracking the 'giant' axon of the Aplysia, the personal, narrating the multi-layered sensorial and emotional landscape of a remembered youth, and the social witnessing of a critical time and place in history.

"Memory", wrote Squire and Kandel "is the glue that binds our mental life, the scaffolding that holds our personal history and that makes it possible to grow and change throughout life" (1999: ix). Following from this, is heritage the scaffolding that holds social memory in place such that together they bind a collective history and make it possible for society to evolve? Or is this a confounding metaphorical leap? Understanding the physical manifestation or locus of something as elusive as memory is not an easy task and the apparently simple marriage of memory and heritage needs to be approached cautiously: "(...) it is clear that the relationship between objects and memory is less straightforward than Western thinking has been in the habit of assuming. We cannot take it for granted that artefacts act as the agents of collective memory, nor can they be relied upon to prolong it" (Forty \& Küchler 2001: 7). Memory is, nonetheless, undeniably a central piece of the theoretical heritage framework that we have been building over the past few years - expanding the boundaries of the concept well beyond the restraints of the single monument. While a 'theory of memory for heritage' might not be what is called for, more deliberate work explicitly unpacking the dynamics that bind memory and heritage together is necessary. This would help construe at least a theoretical framework for thinking about the memory-heritage dyad that might avoid assumptions and misappropriations. Steven Rose writes that "the enigma of memory, as with so many aspects of brain processes, seems to be that it is both localized and nonlocalized" (Rose, 2010: 208) and this enigma is also at the heart of heritage.

The aim of this essay in tackling the heritage-memory alloy has been to clear-up the vocabulary used at the intersection between the two concepts and to give an overview of emerging fields and relevant developments in other disciplines. This chapter began with a consideration of the lexicon being used to refer to the relationship between heritage and memory. One development in the use of language in particular reflects a change in how we think about heritage that suggests future directions for theoretical work. As mentioned above, Ricoeur (2004) saw memory as both a form of knowledge and a form of action. The evolution in our appreciation of heritage from being an object that relays information to a process that constructs meaning indicates that this dual function is equally relevant. The action aspect of heritage is also reflected in recent linguistic developments in both Spanish and French that have begun to use an active form of the word: patrimonialización and patrimonialisation in the two languages respectively.

Memory and heritage studies share a number of areas of interest that are at the heart of contemporary political debates. Both are concerned with the politics of the past in the present and with the effects of dislocation as people, and objects, move away from familiar surroundings to new ones laden with different memory and heritage fabrics. Despite the overlapping interests however, heritage studies more directly focuses precisely on those memory triggers that also act as props for narratives of identity and belonging. One of the paradoxes of heritage is that heritage sites appear to act as anchors, fixing narratives of memory and history, identity and belonging, to places and people, or, more intangibly, as bookmarks indicating key passages in these narratives. Yet, recent research has highlighted the malleability, multifacetedness, and indeed, changeability of how these sites are read, the values that they are seen to uphold, and the narratives that they are supposed to provide tangible evidence for. Developments in the cognitive psychology and neuroscience of memory indicate that individual memory too is malleable, multifaceted, and motored through a process of assemblage determined by a combination of triggers which fire differently depending on circumstance - a process that heritage researchers recognise all too well. Sean Haldane, poet and neuroscientist, writes: "we certainly are not ourselves without memory" (cited in Adams, 2010); the question for us is whether a social collective can be without heritage.

As we have seen, even the most basic memory dynamic of inscribing input that can become output speaks to ideas of perception and projection that are central to heritage thinking. If we also take into account recent developments in the neuroscience of memory that see it as a process of construction, of remembering the past and imagining the future (Schacter \& Addis, 2007) then other fundamental dynamics of heritage such as interpretation, reproduction, narration and imagination (as a process of creating meaning) also come to the fore at the meetingpoint between the two concepts. As Steven Rose writes: "Far from passively recording the past, we in our memories actively reconstruct it" (Rose, 2010: 207). For heritage work, one of the central questions here is whether advances in understanding how memory is encoded, stored, retrieved, and lost in the brain can inform heritage theory or whether this crossover will remain metaphorical. Undoubtedly, for those working in the domain of heritage it will continue to be an enriching and thought-pro- 
voking exercise to follow developments in the science of memory. And there will be ground for exciting conversations and cross-fertilization as developments in the understanding of memory's dynamics continue to develop in various disciplines. In doing so however, our use of the vocabulary of memory needs to be deliberate, being explicit when uses of borrowed terms are metaphorical, and developing terms specifically attuned to the needs of heritage work that are less likely to create false associations.

Politics is an ingredient of heritage that is difficult to avoid, and the presence of politics in the mix expands the temporal scope of heritage, for politics is a project of today that seeks power in order to influence the shape of tomorrow (Isar, Viejo-Rose, Anheier, 2011:3). In this equation the past is an instrument that serves the needs of the present and the aspirations for the future. Curiously, it would appear that cognitive memory also serves this function, serving the needs of an individual faced with the circumstances of a given moment in order to inform decisions about what to do next and make projections about the future. To develop a heritage framework of theory and methods of memory-work it will be important to expand our theoretical basis from Halbwachs, Ricoeur, Nora, to include, as some have begun to do, Ebbinghaus, Bartlett, and those who subsequently built on their work.

Heritage has come to resemble a protean creature: each time one gets a hold of its tail it changes shape. This complicates the task of pinning it down to one concrete definition; a task made all the more difficult by the fact that the key concepts that go into the assemblage piece are just as complex and mobile. Memory is just one of these key concepts. As concerns ways forward in developing a theory of memory pertinent for heritage studies, this author intends to pursue it on three fronts. The first will be to follow developments in cognitive psychology and neuroscience of memory in order to continue concretising frameworks for thinking about the dynamics of heritage and exploring new directions. The second will be to reflect more thoroughly on how the concept of memes might help to refine ideas about cultural inheritance, and heritage, as a form of transmission - partly through mimicry. And the final front will be, returning to social understandings of remembering, to consider the implications of public acts of memory - deliberately remembering and reminding in a social context — for ideas about citizenship, its associated rights and duties, and how it informs our negotiation of uncertainty in relation to decision-making about the future. This will consider work done on the 'ethics of memory' (Margalit, 2002) in order to see how that might inform an 'ethics of heritage'.

If we go back momentarily to philosophical and poetic explorations of memory, for St Augustine (see Confessions) and T.S. Eliot (see Four Quartets and The Wasteland) memory 'is a gathering place for time' (Wetzel, 1995: 355), so too cultural heritage is a gathering place for memory. In line with current ideas on the spread of information and knowledge, the models for understanding both memory and heritage that are emerging have moved on considerably from a hierarchical vision by which the brain and social authorities ran the show, to one of a web-like network of interconnections, and finally to today' s 'cloud' model whose flexible, free-floating mesh is held together through a symbiotic balance of inputs and outputs. And this cloud bears an uncanny resemblance to the 'world-memory' proposed by Deleuze (1989) where no one singularity of person, place or group stands out of a continuum of life made up of metamorphoses, and perhaps also metaphors.

\section{ACKNOWLEDGEMENTS}

The author would like to thank Paola Filippucci, Catherine Charlwood, Chad Dodson, and Pablo Alonso Gonzalez for reading and commenting on earlier versions of this article. The work leading up to this paper and its writing was carried out as part of research project made possible by a British Academy Post-doctoral Fellowship (2011-2014) for which the author is ever grateful.

\section{NOTES}

1 'Thick description' is a concept and analytic tool developed by the anthropologist Clifford Geertz (1973) as a means of interpretative thinking and writing about the multiple meanings of gestures and behaviors.

2 NB Halbwachs from the 1920s, 'Cadres Sociaux' is 1925.

3 The author is currently working on an exploration of heritage dichotomies of which this is a significant one.

4 For an extensive discussion of this relationship and a proposed breakdown of how it evolved through five stages see Jacques Le Goff's History and Memory (1992: 51-99).

5 Rather than coincidence, of course, this is due to a lieu de mémoire that the authors share: the seven deadly sins.

6 i.e. Areas that activate hormones, emotional behaviour, promote reflexes, and sympathetic activation.

\section{REFERENCES}

Adams, Tim (2010) "Interview with Sean Haldane." The Observer, Sunday 30 May, at: www.guardian.co.uk/theobserver/2010/ may/30/sean-haldane-poet-neuroscientist [consulted 16/September/2015]

Anderson, Benedict (1983) Imagined Communities. Verso, London.

Antze, Paul and Michael Lambeck (eds.) (1996) Tense Past: Cultural Essays in Trauma and Memory. Routledge, New York.

Ashworth, Gregory and John E. Tunbridge (1996) Dissonant Heritage: The Management of the Past as a Resource in Conflict. Wiley, Chichester.

Assmann Aleida (2004) "Four Formats of Memory: From Individual to Collective Constructions of the Past." In Cultural Memory and Historical Consciousness in the German-Speaking World Since 1950, edited by C. Emden and D. Midgley. Peter Lang, Bern: 19-37.

Augé, Marc (2004) Oblivion. University of Minnesota Press, Minneapolis.

Augustine, St. (1991 [400]) Confessions, translation by H. Chadwick. Oxford University Press, Oxford.

Bal, Miekke (1999) "Introduction." In Acts of Memory: Cultural Recall in the Present, edited by M. Bal, J. Crewe, and L. Spitzer. University Press of New England, Hanover, NH: viixvii.

Barash, Jeffrey A. (2011) "At the Threshold of Memory: Collective Memory between Personal Experience and Political Identity." In META: Research in Hermeneutics, Phenomenology, and Practical Philosophy, vol. III (2) December: 249-267. 
Bartlett Frederic (1932) Remembering. A Study in Experimental and Social Psychology. Cambridge University Press, Cambridge.

Barthes, Roland (1973 [1957]) Mythologies, translation by A. Lavers. Paladin, London.

Benton, Tim (ed.) (2010) Understanding Heritage and Memory. Manchester University Press, Manchester.

Bergson, Henri (1991 [1896]) Matter and Memory, translation by N. M. Paul and W. S. Palmer. Zone Books, New York.

Bevan, Robert (2006) The Destruction of Memory: Architecture at War.Reaktion, London.

Blackmore, Susan (1999) The Meme Machine. Oxford University Press, Oxford.

Brodie, Richard (1996) Virus of the Mind: The New Science of the Meme. Integral Press, Seattle.

Burke, Lucy and Simon Faulkner (2010) "Introduction: Memory is Ordinary.", In The Politics of Cultural Memory, edited by L. Burke, S. Faulkner, and J. Aulich. Cambridge Scholars Publishing, Newcastle upon Tyne: 1-25.

Chen, Ingfei (2012) "A Feeling for the Past." Scientific American, January/February:24-31.

Connerton, Paul (2008) "Seven Types of Forgetting." Memory Studies, 1: 59-71.

Dawkins, Richard (1993) "Viruses of the Mind." In Dennett and his Critics: Demystifying Mind, edited by B. Dahlbohm. Blackwell, Oxford: 13-27.

Deleuze, Gilles (1989) Cinema 2: The Time Image, translation by H. Tomlinson \& R. Galeta. Athlone, London.

Dennett, Daniel (1995) Darwin's Dangerous Idea. Penguin, London.

Doss, Erica (2008) "Memorial Mania." Museum, American Association of Museums,March/April: 36-43.

Ebbinghaus, Hermann (1964 [1885]) Memory: A Contribution to Experimental Psychology [Uber das Gedächtnis].Columbia University, Teacher's College, New York.

Elsner, Jas (2003) "Iconoclasm and the preservation of memory." In Monuments and Memory, Made and Unmade, edited by R. Nelson \& M. Olin. University of Chicago Press, Chicago: 209-32.

Erll, Astrid (2011) Memory in Culture, Translated by S.B. Young. Palgrave Macmillan, Basingstoke.

Esposito, Elena (2008) "Social Forgetting: A Systems-Theory Approach." In Cultural Memory Studies: An International and Interdisciplinary Handbook, edited by A. Erll and A. Nünning. de Gruyter, Berlin/New York: 181-190.

Etkind, Alexander (2010) "Memory Events in the Transnational Space." Paper presented at the Memory at War Inaugural Workshop. King's College, Cambridge, June 2010. Available on-line at: www.memoryatwar.org/pdf/Etkind $\% 20$ memory $\% 20$ events $\%$ 20paper\%20June\%202010.pdf

Fine, Ellen S. (1988) "The Absent Memory: The Act of Writing in Post-Holocaust French Literature." In Writing and the Holocaust, edited by B. Lang. Holmes and Meier,New York: 41-57.

Forty, Adrian and Susanne Küchler (eds.) (2001) The Art of Forgetting. Berg, Oxford.

Garcia-Bajos, Elvira, Malen Migueles and Michael C. Anderson (2009) "Script knowledge modulates retrieval-induced forgetting for eyewitness events." Memory, 17(1): 92-103

Garden, Mary-Catherine (2006) "The Heritagescape: Looking at Landscapes of the Past." International Journal of Heritage Studies, September, 12 (5): 394-411.

Garton Ash, Timothy (2008) "There are no wrong answers in history." The Guardian Weekly, Comment \& Debate section, 24 Oct: 24.

Halbwachs, Maurice (1980 [1950]) The Collective Memory [La mémoire collective], translated by F.J. Ditter, Jr. \& V. Yazdi Ditter Harper and Row, New York.

Halbwachs, Maurice (1992) On Collective Memory, edited and translated by L. Coser. Chicago University Press, Chicago.

Halbwachs, Maurice (1994 [1925]) Les cadres sociaux de la mémoire. Albin Michel, Paris.

Hebb, Donald O. (1949) The Organization of Behaviour. Wiley, New York.

Hirsch, Marianne (2008) "The Generation of Postmemory." Poetics Today, 29 (1) (Spring): 103-128.
Hobsbawm, Eric and Terence Ranger (eds.) (1983) The Invention of Tradition.Cambridge University Press, Cambridge.

Hobsbawm, Eric (2012) "Hobsbawm: A Life in History." Interview by S. Schama on BBC Radio 4, first broadcast: Saturday 14 April 2012, 20:00.

Hoffman, Eva (2004) After such Knowledge: Memory, History, and the Legacy of the Holocaust. Public Affairs, New York.

Hoffman, Susanne and Anthony Oliver-Smith, (eds.) (2002) Catastrophe \& Culture: The Anthropology of Disaster. James Currey, Oxford.

Huyssen, Andreas (1995) Twilight Memories: Marking Time in a Culture of Amnesia. Routledge, New York.

Isar, Yudhishthir R., Dacia Viejo-Rose and Helmut Anheier (2011) "Introduction." In Cultures and Globalization: Heritage, Memory and Identity, edited by Y.R. Isar, H.K. Anheier and D. Viejo-Rose. Sage,London: 1-18.

Jones, Andrew (2007) Memory and Material Culture. Cambridge University Press, Cambridge.

Jones, Owain and Joanne Garde-Hansen (eds.) (2012). Geography and Memory: Exploitations in Identity and Becoming. Palgrave Macmillan, London.

Jong, Ferdinand de and Mike Rowlands (2007) Reclaiming Heritage: Alternative imaginaries of memory in West Africa. CA: Left Coast Press, Walnut Creek.

Kandel, Eric R. (2006) In Search of Memory: The Emergence of a New Science of Mind. W.W. Norton \& Company, New York.

Kirshenblatt-Gimblett, Barbara (1995) "Theorizing Heritage.” Ecomusicology, Fall, 39(33): 367-380.

Landsberg, Alison (2004) Prosthetic Memory: The Transformation of American Remembrance in the Age of Mass Culture. Columbia University Press, New York.

LeDoux, Joseph E. (2000) "Emotion circuits in the brain." Annual Review of Neuroscience, 23: 154-184.

LeDoux, Joseph E. (2002) "Emotion, Memory and the Brain." Scientific American updated from the June 1994 issue: 62-71.

Legg, Stephen (2007) "Reviewing geographies of memory/forgetting." Environment and Planning A, 39(2): 456-466.

Le Goff, Jacques (1992) History and Memory. Columbia University Press, New York.

Levy, Benjamin J. and Michael C. Anderson (2008) "Individual differences in the suppression of unwanted memories: the executive deficit hypothesis." Acta Psychologica (Amst), 127(3): 623-35.

Lowenthal, David (1996) Possessed by the Past: The Heritage Crusade and the Spoils of History. Free Press, New York.

Lury, Celia (1998) Prosthetic Culture: Photography, Memory, Identity. Routledge, London.

Lynch, Aaron (1996) Thought Contagion: How Belief Spreads through Society. Basic Books, New York.

Margalit, Avishai (2002) The Ethics of Memory. Harvard University Press, Cambridge, MA.

Mishkin, Mortimer and Tim Appenzeller (1987) "Anatomy of Memory." Scientific American: 80-89.

Moore, Niamh and Yvonne Whelan (eds.) (2007) Heritage, Memory and the Politics of Identity. Ashgate, Aldershot.

Nietzsche, Friedrich (1980 [1974]) On the Advantages and Disadvantages of History for Life. Hacket Publishing, Cambridge.

Nora, Pierre (ed) (1984-1992) Les Lieux de Mémoire, 7 vols. Gallimard, Paris.

Nora, Pierre (1989) "Between Memory and History." Representations 26, Spring: 7-24.

Nora, Pierre (1996-1998) Realms of Memory: Rethinking the French Past, edited by L. D. Kritzman, 3 vols. Columbia University Press, New York.

Olick, Jeffrey (1999) "Collective Memory. Two Cultures." Sociological Theory, 17 (3): 333-348.

Olick, Jeffrey K., Vered Vinitzky-Seroussi and Daniel Levy (eds) (2011) The Collective Memory Reader. Oxford University Press, Oxford.

Raczymow, Henri (1979) "La Mémoire Trouée." Pardès, 3: 177-182.

Radstone, Susannah (2008) "Memory Studies: For and Against." Memory Studies, 1 (1): 31-39. 
Radstone, Susannah and Katharine Hodgkin (2003) "Introduction: Contested Pasts." In Contested Pasts: The Politics of Memory, edited by S. Radstone and K. Hodgkin. Routledge, London: $1-21$.

Radstone, Susannah and Bill Schwarz, (eds.) (2010) Memory: Histories, Theories, Debates. Fordham University Press, New York.

Ricoeur, Paul (2004 [2000]) Memory, History, Forgetting. University of Chicago Press, Chicago.

Roediger Henry L. and James V. Wertsch (2008) "Creating a New Discipline of Memory Studies." Memory Studies, 1 (9): 9-22.

Rose, Steven (2010) "Memories Are Made of This." In Memory: Histories, Theories, Debates, edited by S. Radstone \& B. Schwarz. Fordham University Press, New York.

Schacter, Daniel L. (2001) The Seven Sins of Memory: How the Mind Forgets and Remembers. Houghton Mifflin, Boston.

Schacter, Daniel L. and Donna Rose Addis (2007) "The Cognitive Neuroscience of Constructive Memory: Remembering the Past and Imagining the Future." Philosophical Transactions of the Royal Society B, 362: 773-786.

Smith, Laurajane (2006) The Uses of Heritage. Routledge, London. Squire, Larry R. and Eric R. Kandel (1999) Memory: from Mind to Molecules. Scientific American Library, New York.

Sørensen, Marie Louise S. (1996) "The Fall of a nation. The Birth of a Subject: The National Use of Archaeology in Nineteenthcentury Denmark." In Nationalism and Archaeology in Europe, edited by Diaz-Andreu and Champion. UCL Press, London.
Tulving, Endel (2007) “Are there 256 Kinds of Memory?" In The Foundations of Remembering: Essays in Honor of Henry L. Roediger, edited by J.S. Nairne. Psychology Press, New York: 40-52.

Ugresić, Dubravka (1996) "The Confiscation of Memory." New Left Review, 218, July/August: 26-39.

van Dijck, Jose (2004) "Mediated memories: personal cultural memory as object of cultural analysis." Continuum: Journal of Media \& Cultural Studies, 18 (2): 261-277.

Viejo-Rose, Dacia (2011) Reconstructing Spain: Cultural Heritage and Memory after Civil War. Sussex Academic Press, Eastbourne.

Wertsch, James V. (2002) Voices of Collective Remembering. Cambridge University Press, Cambridge.

Wetzel, James (1995) “Time after Augustine." Religious Studies, September, 31 (3): 341-357.

Wilson, Ross (2009) "Review Article: History, Memory and Heritage." International Journal of Heritage Studies, July, 15 (4): 374-378.

Winter, Jay (1999) Sites of Memory, Sites of Mourning: The Great War in European Cultural History. Cambridge University Press, Cambridge.

Winter, Jay (2000) "The Generation of Memory: Reflections on the 'Memory Boom'." Contemporary Historical Studies: Bulletin of the German Historical Institute, 27: 80-82.

Winter, Jay (2010), "Sites of Memory." In Memory: Histories, Theories, Debates, edited by S. Radstone and B. Schwarz. Fordham University Press, New York: 312-324.

Woodward, Christopher (2002) In Ruins. Vintage, London. 